Ireneusz Skawina

University of Social Sciences

Elżbieta Markiewicz

University of Social Sciences

\title{
The Evaluation of the Readiness of the child for the Early-school Education in the Context of the Indicators of the School Maturity - the Model of the Mature Child Ready for Education
}

\begin{abstract}
At a time of successively implemented educational reforms on the level of early-school education, presently concerning the youngest generation of Poles, there is an exquisitely topical question about the school maturity of the contemporary child. Hence, an attempt to turn attention to proper preparing the child for taking the compulsory education is a priority objective of the present article. The attention should be also turned to the essential role in this implementation process for the system and methodological education which is a basic education environment - a family.

Authors, having exploited the expository method as fundamental form of the realization of the established purpose, made an attempt to depict not only a substantial role of the early-school education (by stressing the appropriate intellectual, emotional and social development of the child), but also to define school maturity indicators and determinants. It was also underlined, that the appropriate assessment of the child's school maturity constituted the essential determinant of his proper functioning in the school environment. Additionally, an attempt was made to depict the model of the mature child ready for the early-school education through indicating factors which determine acceptable readiness. A return to the current issues of imposing compulsory education on 6-year-old children was also made.
\end{abstract}

Key words: school readiness, maturity, compulsory education, child, education. 


\section{Introduction}

From the first days of every man's life, first and at the same time the closest education environment for him is a family. It conditions through economicsocial factors, adopted educational style (model) and recognised system of norms and values, the quality and the pace of development of its youngest members - children. Therefore, proper impelling the child, already in the home environment, for taking diverse (albeit adjusted to the age) duties and imposing the requirements of accepting family rules, constitute fundamental preparation of the child to function in the institutional environments (the nursery, the preschool or the school). It seems that starting the school education by the child begins one of the most important stages in his life. Transition from the pre-school age to the early-school age constitutes the essential change and the reorganization of his current functioning. It translates into a certain, even a radical one, transformation in acquiring and discovering by the child the surrounding world - not by the means of having fun, but by methodological and structurally organised process. From now on, the achievements become a basic criterion of the assessment of the child. In this climactic moment one should just remember to check, whether the child is mature enough to take on the challenge connected with learning at school [Horsonek 2001, p. 2]. To put it simply, school maturity is nothing less than the readiness of the child to undertake duties and tasks waiting at school. The maturity understood that way is conditioned by: physical and psychological development (i.e. emotional, social and intellectual) as well as, as far as possible, acquiring the knowledge and skills that should properly prepare the child to learn how to read, write and count. Correctly formed maturity of the child and the teachers' attitude in the adaptation of the child to the school environment, imply the increasing chances of the child to be successful at school as well as the effectiveness of his development.

\section{The participation and the importance of education in the life of the child}

The education of each of us, in the first years of life, is significant, since our intellectual, emotional, physical and social development depends on its quality. Hence, proper forming of this process prevents irregularities and the disharmony, as well as creates conditions to shape the personality and character of the child. At that time, every child gets to know and expresses himself as well as learns how to communicate successfully with the surrounding world. In the earlyschool education, the scope of knowledge that should be passed on to children does not require the multistage and complex expertise. Teachers can make use of diverse and carefully prepared scripts and readymade teaching aids. It seems that everyone could become a teacher of the primary education, however, only 
expertise will not be enough. The teacher should have a suitable personality [Dziurzyńska 2008, pp. 56-59].

Giving some thought to the causes, for which educational-pedagogic process is a duty from the education level of early-school, we can explicitly point at the element of the education. It is tantamount to teaching and learning, which conditions the substantial changes in the behaviour. Whereas these changes should be understood as certain conversions in emotional-social, cognitive and physical attitudes.

Formally, the education system is structuralized which means that it composes the string of mutually conditioning stages. A pre-school is the first stage, where children are being prepared to take on the role of the pupil. It means that abilities acquired at this stage will be deepened and extended during further stages of the education. An early-school education is a next level. During this stage, for the first three years, the child learns basic abilities which are essential to continue the learning process. Next, the pupil receives the elementary education which lets him function better in the environment and continue education on the level of the junior secondary school. In this moment the child's education becomes more specified, adapted to his possibility, interests and talents. The next step is the choice of the secondary school and then the higher education institution. However, this choice is at the sole discretion of the student [Galloway 1998, p. 10].

In the perspective of the foregoing deliberations, it is essential to take a long hard look at the early-school education as the first, compulsory step of the organised education. Contemporarily, in the subject literature one can come across diverse expressions i.e.: the integrated education, the elementary education, or the primary education, early-school. According to Więckowski [1995, p. 32] “(...) the essence of the early-school education is its introductory nature. It does not exclusively or almost exclusively come down to preparing the child for the further education on higher levels, but above all make a child familiar, owing to the child's own activity, with ways or techniques of the mental work". It means that the education on the early-school level establishes essential goals for the intellectual, emotional and social development. These goals when correctly achieved can determine certain attitudes and future behaviour. They include, among others: establishing and keeping correct contacts with peers, proper action in school and outside school situations, the appropriate manner of communicating with surroundings.

To start early-school or pre-school education, a child should be emotionally, socially and mentally developed so that it can cope without problems with the new obligations. Everyone who begins this period of learning, has a diversified level of the acquired and absorbed knowledge and abilities as well as the individual 
personality features. Assessing the readiness for the child's early-school education should, as a priority, analyse all spheres of the development, and simultaneously accept his individuality and autonomism. The physical readiness of the child to start the school education manifests itself in the medical condition which takes into account the motor, manual skills as well as mobility, the correctness of functioning of hearing organs and the eyesight, resistance to the tiredness, illnesses of different kind or also the effort. However, the emotional readiness is an ability to handle own emotions and control them appropriately to the age. The lack of emotional readiness can result in outbursts of anger, crying, conflicts with peers, aggression, or fears. However, the social readiness is defined as the ability to establish contacts and interact with surroundings. Achieving the social readiness manifests itself through the level of the self-reliance and resourcefulness of the child in different situations e.g. his reliability or carrying out theestablished objectives. An intellectual readiness is the last readiness to start the compulsory education. It is constituted, according to Czech [2009, p. 1] by appropriate to the age:

a. development of the speech - the child is able to express, to talk freely and comprehensibly for the surrounding, to ask, to articulate words, and has a set of vocabulary and notions adequate to the age;

b. level of mental operations - the child understands connections between facts, is able to interpret existing situations, picture stories, illustrations, understands instructing as well as instructions for tasks, is competently in touch with the most immediate environment; the level of the visual-aural perception and visual-aural-motor coordination - the child possesses analytical and visual and aural synthesis skills which are necessary in the diversifying process or to recognize shapes and sounds;

c. level of the concentration of the attention - the child is able to carefully and with understanding listen to what the teacher says, understands and carries out instructions given to him, and is able to concentrate on conducted tasks.

It seems the school readiness is influenced by the results of the cooperation of two processes i.e.: maturing and learning. They depend, in great measure, on conditions the child lives in and functions as well as the child's abilities. Thus, the substantial role is being assigned to education trainings in the home environment [Wilgocka-Okoń 1999, p. 16].

For every child, a contact with the surrounding and peer interactions of different kind e.g. team classes are extremely important.

Unfortunately, one may notice that establishing area which should be taken into consideration while assessing the readiness for the early-school education is not an object of disputes, however, the essential and required level the individual should achieve is difficult to establish. There is a belief that it is not possible to 
determine this level explicitly in the general way. We can enumerate three basic factors that influence early-school readiness. They are connected with the child as the individual, with home and school environment. Spontaneous and ill-advised assessing these factors will influence the subsequent development of the child in the negative way, and at a later time can even be a reason of stopping the activity and the creative attitude in the face of commissioned tasks. The appropriate assessment of the early-school readiness should serve as the proper promotion of the child's development. On this basis, there are influences designed taking child's individual social and educational needs into account. In this evaluation one should remember about the relation between possibilities of the child and what school environment has to offer as well asparents' expectations. A problem of the school maturity associated with giving equal opportunity and preventing failures of children having developmental problems and coming from families of lower social status has been always appearing in the Polish pedagogic tradition. Actions which are being taken, in the area of the evaluation of the suitable school readiness, consist of providing children with equal life and educational chances and the improvement in their quality of life. Increasing the access to education, overcoming the barriers or decreasing the educational disproportions between different environments enriches the social sense of the school readiness evaluation [Frydrychowicz, Koźniewska, Matuszewski 2006, p. 6].

Research conducted in 2002 aimed at portraying the percentage of children's full, partial or none success at school. The research also assumed that 12 points collected in the school test conducted to examine the results of the first year pupils is an attainable minimum. This number of points assured that the child counts, understands mutually opposite amount relations and knows how to use them, writes and reads with understanding. Scoring 7 points is a minimum of the partial success in the learning process (the child counts, poorly writes and reads). The achievements were juxtaposed accepting discussed borders of success and the following results were received:

Table 1. The number and the percentage of children in terms of their success in learning

\begin{tabular}{|l|l|l|l|l|}
\hline & \multicolumn{3}{|l|}{ Success in learning } & \multicolumn{2}{l|}{ Total } \\
\hline & Full & Partial & None & \\
& & & & \\
\hline
\end{tabular}




\begin{tabular}{|l|l|l|l|l|l|}
\hline City & $\begin{array}{l}\text { Number of } \\
\text { pupils }\end{array}$ & 183 & 17 & 4 & 204 \\
\cline { 2 - 7 } & $\%$ & 90 & 8 & 2 & 100 \\
\hline Village & $\begin{array}{l}\text { Number of } \\
\text { pupils }\end{array}$ & 202 & 51 & 12 & 265 \\
\cline { 2 - 7 } & & 76 & 19 & 5 & 100 \\
\hline
\end{tabular}

Source: Wilgocka-Okoń 2003, p. 64.

On the grounds of the above data, we conclude that about $2 \%$ pupils living in the city and the 5\% living in the countryside show the lack of the school success. In order to correct it, one should provide these children with special psycho-pedagogical and medical care. As for children with the partial school success i.e. the $8 \%$ in the city and the $19 \%$ in the country, one should employ pedagogic-educational methods which will help them fill developmental gaps. On the grounds of there search, conducted in order to check the level of the success at school, we can come to the conclusion that children with the very good school readiness have $95 \%$ of chances of the full success in the school and the $5 \%$ of the partial one. In turn children with the good school readiness can have $75 \%$ chances of the full success and $24 \%$ of the partial one and just $1 \%$ of none success. However, children with just sufficient school readiness have 35\% chances of full success and $60 \%$ of the partial one and finally $5 \%$ chances of failure. The last group of children who are not ready for school education can have $15 \%$ chances of a full success at school, $65 \%$ of only partial one and $20 \%$ for the lack of success [Wilgocka-Okoń 2003, p. 64].

Presented numbers from the research depict that in principle every child joining the school is having measurable chances of the success. However, they are very diversified - they depend, among others, on the degree of the readiness of the child to start school duties but also, on the pedagogic - educational level of a given school. Programs conducted by schools, school books, schools equipment, appliances and teaching aids are decisive when it comes to evaluating the above mentioned level. However, the most important element influencing the initial teaching and the upbringing, is the teacher's work, values he holds and the methods and the forms of organisation of his work [Wilgocka-Okon 2003, 
p. 65]. At the same time, one should remember about the fact that children in the early-school age ask a huge amount of questions. They are very discerning which may many times can cause embarrassment to many adults. That results in the situation when adults unconsciously go into depths while answering the questions. That way they manifest their knowledge or on the contrary - ignore the child. Therefore, the responsible educator should know that treating a child as equal, in almost every situation, is the most important.

Although the development potential of the preschool children is the greatest, they acquire a lot of experience and knowledge at that time, one should take into account, that the strongest influence has an environment in which they live and function. It is the first period and the stage of creating educational inequalities, deficits or also the developmental disorders as a result of environmental conditioning, since they are remarkably diversified in economic and intellectual terms. The pre-school period is a good time for eliminating different shortcomings in the development, caused by wrong functioning of the home environment [Włoch, Włoch 2009, p. 21].

\section{Base criteria of the school maturity}

For every child who starts the compulsory education, educational achievements will be the main purposes. However, a child must reach the school maturity so that it can meet school requirements and develop fully. This maturity is interchangeably named: school readiness or the preparation for the school. The difference which exists between above mentioned notions may constitute the understanding of the core and mechanisms of the adolescence and may define the role of the learning in the developmental process. When we talk about the school maturity, we mean achieving by the child such an intellectual, emotional, social and physical degree of the development which enables him to participate in the school life and to master the curriculum in the first class. Child who is mature enough to begin the education, displays the interests in spite of failures that he could come across, always achieves at least minimal progress in the learning process [Okon 2004, pp. 71-72]. The notion of school maturity regards the relation between the school environment, the home environment and the child. The stage, in which the child finishes the pre-school and begins learning at school is a huge challenge and an experience, and the good "start" at the new school will play a great role in the entire course of the school career. The degree of the psychophysical maturity and the pre-school preparation plays very important role in achieving school successes of the child when he starts the new phase of his life. One should remember that every child develops at his own pace, and the school readiness is not only decided by the pupil'sage, but also achieving the appropriate level of development. A few basic developmental spheres exist. Their degree of 
maturity is treated as the criterion of the full school readiness. They include: physical, intellectual, and emotional-social sphere as well as the state of the child's speech. The appropriate maturity of above mentioned spheres decides about the readiness for learning to read, write and the learning of mathematics [WilgockaOkoń 1999, pp. 12-13].

Maturity in the physical sphere regards the normal manual and motor development of the child conditioned by the appropriate physical development of the whole organism (it is about an appropriate development of viscera, nervous system, sense organs), they also include: manual dexterity and graphomotoric skills, the correct structure of the articulatory organ. Providing the child with a lot of movement is an important factor. If the child moves firmly as well as uses his own body surely, it results in a greater feeling of self-confidence. Therefore, it is important to motivate the child to be active. The activities include among others: the gymnastics or doing sport. Amongst the ways which will influence the good physical fitness and support the coordination of the whole body as well as the manual dexterity, we can enumerate:

- swimming, gymnastics, dance;

- games and games involving physical movement in the fresh air e.g. ball games, skipping rope, rollerblades;

- moulding plasticine, modelling clays; cutting out, sticking, games with salt mass;

- games involving construction, tinkering;

- finger painting or painting with the entire palm.

Mental maturity (intellectual) is responsible for the appropriate intellectual developmenti.e. spotting, thinking, speech, memory. The child who is intellectually mature is interested not only in learning, but everything that surrounds him. It has an ability to listen with comprehension, expresses freely, listens to and carries out instructions, is able to concentrate on something, to focus, is able to draw conclusions and to assess, easily learns new things, and is able to use acquired knowledge practically. To practise and develop the mind of the child, it is possible to perform the following exercises:

- doing jigsaws, arranging according to the pattern and without the pattern, beginning with exercises with the pattern;

- training in distinguishing the shapes;

- playing with blocks, building the structures;

- exercising the memory - remembering details of pictures and then enumerating everything remembered by the child.

The last one, emotional-social maturity, is a child's ability to comply with the norms and principles applicable in a given group. A child who is emotionallysocially mature: 
- is interested in learning;

- is persistent, and tries to overcome potential obstacles;

- is able to wait for his turn;

- can cooperate in a peer group, is able to subordinate himself to standing rules and principles;

- finishes the commenced task;

- is able to behave accordingly to the given situation.

The state of the speech also performs very important function in the child's full early-school education readiness. At the age of 7 , the child should achieve the full maturity in speech i.e. should know and practise easy complex grammatical forms of his mother tongue. The child should tell brief stories or create dialogues keenly. However, we should remember about the fact that the intellectual development always progresses individually, it depends, among others, on the stimulation of the environment or an intellectual development as well. The state of speech is to a great extent the decisive factor when it comes to assessing the readiness to start the education at school.

For proper functioning at school a spatial orientation is also essential, namely that the child should distinguish sides of the body, directions in the space and on the sheet. The exercises that support these abilities include:

- showing and naming the individual body parts;

- using above, under, before, beside expressions while having fun;

- drawing in accordance with instructions e.g. draw the circle in the middle of the sheet.

The main and at the same time the most important factors of the school maturity include:

- Environmental factors - which comprise: influences of the preschool and the family. There are three basic family determinants which have a significant influence on the school maturity of the child. They include: a) financial situation - it is one of these most important factors, the income that the house generates, and the level of the household equipment or the housing situation decide whether the family will be able to meet the needs of the child, i.e. whether it can provide appropriate conditions for child's learning, play, rest etc.; b) cultural conditions - here we talk about parent's level of education, their proper language standards, the principles according to which they raise their children, and the way of spending time with children. It all largely affects the intellectual development of the child and his achievements in school; c) psychological-social conditions - they concern the personality of parents, their mutual relations and the general atmosphere at home. In order to achieve the school maturity, it is very important whether a child is raised in the complete or incomplete family, little or large one, two or three-generation. Most often a 
large family creates the most favourable terms for the development of child's personality, since it creates protective attitudes and helps to achieve selfreliance much faster. However, it happens that in such a numerous families the financial situation is very modest, parents are allotted with a lot of duties which translates into the smaller amount of time which is left to be devoted to the child.

- Individual factors - they are inborn, or passed over by the genetic properties of the organism, especially a central nervous system - the base of all higher psychological action. The tendencies, needs and aspirations of every child are distinguished [Brejnak 2005, pp. 14-20].

Appropriate determining the child's school maturity, on all levels of his development, seems to be the qualifying task for realizing the child's intellectual and personal potential, which transfers into the future educational success. Unfortunately, as conducted research shows about 30-40\% children does not achieve the optimum school readiness when beginning their school presence. However, after about six months of learning, development accelerates and children start functioning in the school environment without considerable problems. Nevertheless, some children have major problems with mastering material which can lead to failures. Furthermore these failures can have side effects in the form of fears of the defeat. It implies school neurosis, states of the pressure (they are the sources of aggressive behaviours), unwillingness to go to school and the like.

There were many tests created for the appropriate assessment of the child's school maturity. They aim at examining, among others, verbal and nonverbalabilities of child. The most important tests include:

a. Herbert Winkler's test - it assumes that the school maturity is a maturity to start the school education, it examines the ability to spot shapes and numbers, ability of observation, the dexterity, visual and motor memory, remembering the contents of the listened text, repeating words, the efficiency of the pronunciation, imaginations, combinations and creating the notions as well as the ability to concentrate;

b. Sancte de Sanctis' test - examines an ability of distinguishing the size of objects, their distance, the evaluation of shapes and weight;

c. Schenk Danzinger's test - consists of examining the social development. It assesses the learning abilities, the abilities of mastering the material, a development of intellectual skills and manual or structural abilities;

d. Alicja Szemińska's test - tasks included in this test require child's complex activities which allow to assess his general attitude towards performed tasks as the condition of the success at school (self-motivation, the accuracy of performing allotted tasks, concentration), intellectual and speech development. Performing all the test tasks is combined with observation of the child in the 
everyday situations which will allow to notice any difficulties that the child experiences and how he behaves. It requires the examiner to have a direct contact with the child;

e. The Test of the School Readiness assesses the degree of children'spreparation to perform the compulsory education in the ages of 5-9 up to $7-8$, child'senvironmental conditioning and the way of filling the developmental gaps if a child has any of them. The main assumption of the test is an assessment of the level of the mental, social and physical maturity which allow the child to actively participate in the school's life. The discussed test examines the intellectual development but first and fore most operational thinking, development of the perceptive-motor efficiency, the ability to use fundamentals in mathematics and reasoning and the tasks included in the test form four basic groups:

- general comparing of graphic symbols and different objects in terms of appearance and individual elements,

- integrating the separate elements and distinguishing them which means making a synthesis and analysis of the specific objects,

- comprehending the sets, understanding their power i.e. the ability of using elementary mathematical notions,

- reasoning which is based on analytical judgements, taking the logical sequences of the events into account [Jarosz, Wysocka 2006, pp. 199-201].

Above mentioned evaluation tests are conducted in two stages, collectively and individually. Earlier, the interview is made with parents as well as documents are analyzed (child's medical record). However, one should remember that conducted examinations, aimed at assessing children's school maturity, are not the only measure applied in this evaluation, since we have to take into account the pace of child's development, the level of teaching at school, and the features of the home and peer environment.

\section{The model of the mature child ready for education. Six-year-old at school}

Most often applied evaluation of the person is the assessment of his maturity. It raises questions about its definability. Maturity is an ambiguous notion. Its basic content is determining the certain stage of human biological development. The measure of this stage can be an appropriate age e.g. in Poland at the age of 18 the person becomes a fully-fledged citizen, albeit not completely mature.

It is also possible to put the maturity in intellectual, cultural, social and emotional categories. There is also a maturity defined in the context of the life experience which is independent of the age [Brejnak 2006, pp. 13-14].

The model of the mature child ready for beginning its school education is tantamount to the characteristics of his development i.e. with analysis of 
appropriate features thanks to which the child starts education in the first class. The mature child should, as previously mentioned, achieve the appropriate degree of the intellectual, physical, social and emotional development. It manifests itself in the ability to perform both tasks and obligations found in a school curriculum. In E. Jarosz's book [2006, p. 76], a model of the school maturity was specified:

- In the range of the physical maturity - the child has a suitable manual dexterity, propervisual-motor coordination, his sense organs function correctly, he demonstrates the great immunity to tiredness and illnesses, and is generally physically fit.

- In the range of the emotional-social maturity - the child is able to be independent, conforms to imposed rules, demonstrates the patience, diligence, is able to control his emotional reactions.

- In the range of the general intellectual maturity - the child is characterized by the eagerness to acquire knowledge, expresses his interest while reading and writing, has a good sense of spatial orientation in the surrounding that the child is in, fulfils and understands instructions given by a teacher, has an ability to tell brief stories.

- In the range of the maturity to reading and writing - the child is characterized by a spatial imagination, is able to perform aural and visual analysis and synthesis, acquired the ability to distinguish shapes and sounds.

- In the range of the maturity to mathematics - is able to determine spatial, quantitative and temporal relations while acting, can add and deduct up to 10. While preparing children for education which awaits them at school i.e. writing, reading and counting, intellectual and other operations get activated. That way, a child learns how to justify, draw conclusions, show reasons and their effects as well as how to use these processes independently. Thus, so much depends on the child's earlier preparation by parents who should creatively improve achievements of their offspring and simultaneously support them both in terms of success and failure.

W. Brejnak [2006, pp. 103-111] determined so-called "ten before-school commandments" which aim at constructive providing the parents with the way to support the adaptation process for starting the compulsory education. Firstly, if necessary, one should consult the right specialist in terms of child's medical condition and fitness. Secondly, one should not frighten the child with the school which can be totally unconscious behaviour of the caretaker. Next, one should help the child, but at the same time do not do his work. Fourthly, one should not tire the child out with studying. Fifthly, one should trigger child's own activity. Sixthly, one should participate in the development of his own child. Next, one should rationally trust the child. Eighthly, one should be just and consistent in enforcing instructions. If we neglect the learning of the child in terms of following 
the established principles and fulfilling duties, it can adversely affect fulfilling school duties. Ninthly, it is necessary to accept child's anxieties and fears and make attempts to have conversations. Tenthly, as the most important, one should show love to a child in every situation and in every possible way.

Recently, there were implemented changes in the school curriculum of the general education and qualifying requirements. "President Bronisław Komorowski signed an amendment to an act concerning the educational system. On its basis, in 2014 the compulsory education for six-year-olds born in the first half of 2008 was introduced. Remaining children who were born this year will begin school education in 2015 "[on-line: 14.10.2014].

Introducing the above mentioned act is tasked to streamline and smoothen the process which began in 2009. The process aims at lowering the age which conditioned the compulsory education of six-year-old children and creating in class I-III of the public primary schools the educational conditions familiar to the child from the pre-school period. According to the amendment introduced by Sejm in August, children who were born in the period between $1^{\text {st }}$ January $-30^{\text {th }}$ June 2008 should go to school obligatorily on $1^{\text {st }}$ September 2014 with seven-yearolds who were born in 2007. However, children born in the second half of 2008 i.e. statutorily from $1^{\text {st }}$ July to $31^{\text {st }}$ December, will obligatorily go to school from $1 \mathrm{~s}^{\mathrm{t}}$ September 2015 along with six-year-old children who were born in $2009^{1}$. At schools where more than one first class will be formed, in the period of school years 2014 / 2015 and 2015 / 2016, pupils will be selected to the classes according to the age, beginning from the youngest ones. In special and justified cases, the parents after submitting the application will have the right not to adhere to this principle (e.g. when their children born in two different years will go to school) [on-line: 14.10.2014]. In this context appears a question whether this regulation is a good direction of transformations of the early-school education. Opinions are really mixed. Some parents made efforts to postpone the compulsory education of their children. The Ministry of National Education was negatively surprised by such response to this amendment. The opponents of the amendment believe that schools are not ready for such radical changes.Namely the schools are in the bad technical condition and are overcrowded etc. Parents worry, that pre-school compulsory education imposed on 6-year-olds, will force them to go to school because of the lack of the pre-schools. On the other hand, the supporters believe

1 The condition of the contemporary education undergoes constant changes on the educatory level. The changes, as perceived by their authors, should serve, as it seems, the increased efficiency of the education quality and adjusting to the contemporary requirements. Consequently, as a result of the introduced reform the threshold of child's school readiness was lowered. The authors of the present article do not deny the idea of lowering the threshold, they only oppose to the mass introduction of this idea. According to their evaluation, it badly affects the individualism and autonomism of the child's educational and pedagogic development. 
that the small child has considerable intellectual abilities which determine the appropriate time for learning. It means, in their perception, the easiness to prevent learning difficulties, since it is possible to eliminate quickly and consistently all environmental negligence and diverse developmental dissonances. Thanks to that, every child will have chances for achieving the school maturity faster and the majority of children will be already to start school education [on-line: 14.10.2014]. However, even in such controversial discussion, should not a child's security be a priority (regardless of the institutional environment), or the respect and affirmation of autonomism and individual developmental pace of every child?

\section{Conclusions}

Educational-pedagogic process takes the considerable part of the human life. Acquiring the knowledge constitutes the permanent development stage which takes place from the birth to the end of life. It translates into acquiring new abilities, experiences and making useof natural individual abilities. As a result, education is the process, generated with the requirements of reality, which undergoes constant transformations and changes offering limitless chances of the own development and improvement to subjects of its influence. As a consequence, the man is able to live together in the community, becomes self-reliant and cooperates with other people.

In the early-school period, a fun is a dominating form of learning which guarantees to the child both expressions and impressions. It is mainly the home environment that has an impact on child's personality and character development as well as on adapting the child to the next educational stages. The appropriate parental attitude towards the systematic teaching process constitutes the crucial element of the child's readiness to begin education in the institutional environment. The school maturity as the form of adequate preparing to fulfil school duties, will provide the stress-free and correct adjustment to the prevailing social life in school and the future life.

\section{Bibliography}

Brejnak W. (2006), Czy Twój przedsžolak dojrzat do nanki?, Wyd. PZWL, Warszawa.

Brejnak W. (2005), Rola rodziny w prrygotowaniu džiecka do nauki cəytania i pisania, „Życie szkoty", no 2, pp. 14-21.

Czech E. (2009), Diagnoza wstępna driecka rozpoczynajacego nanke w klasie 1, Edukacja Polska, Warszawa.

Dziurzyńska T. (2008), Edukacja dziecka- mity i fakty, ,Wychowanie w przedszkolu”, no 10, pp. 55-61.

Frydrychowicz A., Koźniewska E., Matuszewski (2006), Skala gotowości sækolnej, wyd. MPP, Warszawa. 
Galloway Ch. (1998), Psychologia uczenia sie i nauczania, tom I, PWN, Warszawa.

Horsonek M. (2001), Wplyw rodziny na dojrzałość sžolnq dziecka, „Życie Szkoły”, no 8, pp. 1-12.

Jarosz J., Wysocka E. (2006), Diagnoza psychopedagogiczna podstawowe problemy i rozwiazania, wyd. ŻAK, Warszawa.

Jarosz E. (2007), Wybrane obszary diagnozowania pedagogicznego, wyd. UŚ, Katowice.

Okoń W. (2004), Nowy stownik pedagogiczny, wyd. ŻAK, Warszawa.

Więckowski R. (1995), Pedagogika wczesnosækolna, WSiP, Warszawa.

Wilgocka-Okoń B. (1999), Gotowość sžkolna a uczenie się w prz̨edszkolu, „Wychowanie w przedszkolu", no 3, pp.13-21.

Wilgocka-Okoń B. (2003), Gotowość sžkolna dzieci sześsioletnich, wyd. ŻAK, Warszawa.

Włoch A., Włoch S. (2009), Diagnoza catościowa w edukacji przedszkolnej i wczesnoszkolnej, wyd. ŻAK, Warszawa.

on-line: http://prawo.rp.pl/artykul/1056709.html, access 14.11.2014. 